\title{
MEMBANGUN TRADISI PLURALISME DALAM PERSPEKTIF PENDIDIKAN ISLAM
}

\author{
Puspo Nugroho \\ STAIN Salatiga, Jawa Tengah, Indonesia \\ puspo.nugroho@yahoo.com
}

\begin{abstract}
Abstrak
Penelitian ini bertujuan untuk memberikan pemahaman analitis fenomenologis terhadap eksistensi tradisi pluralisme melalui cara pandang dan pemahaman masyarakat setempat. Jenis penelitian ini adalah penelitian kualitatif, menggunakan pendekatan antropologis. Hasil penelitian menujukkan faktor yang mempengaruhi terbentuknya budaya kerukunan beragama mencakup: (a) faktor budaya Islam Jawa, (b) faktor geografis, (c) faktor sosial kemasyarakat, (d) faktor model pemahaman teologis yang inklusif. Model pemahaman teologi Islam terdiri dari: (1) model pemahaman teologi bayani, (2) model pemahaman teologi burhani, dan (3) model pemahaman teologi irfani. Dalam prakteknya, ketiga model pemahaman teologi ini (bayani, burhani, dan 'irfani) terinterkoneksi dalam memahami realitas sosial. Sementara model pemahaman teologi Kristen terdiri dari: model pemahaman teologi Kristen periode pra akademis, periode akademis, dan periode akademis-kontekstual.
\end{abstract}

Kata kunci : pluralisme, agama, tradisi.

\section{Abstract}

DEVELOPING PLURALISM TRADITION IN ISLAMIC EDUCATION PERSPECTIVE. This study aims to provide a phenomenological analytical understanding of the pluralism tradition 
Puspo Nugroho

existence through the local community perspective and understanding. This research was a qualitative research by using anthropological approach. The consideration was that the research object was anthropological (the culture). The results showed the factors that affect a culture of religious harmony include: (a) factors of Java Islamic culture, (b) geographic factors, (c) social factors, (d) inclusive factors or model of theological understanding. Understanding model of Islamic theology consists of: (1) model of Baiyani theology, (2) model of Burhani theology, and (3) model of 'Irfani theology. In practice, these three models of theological understanding (Bayani, Burhani, and 'Irfani) are interconnected in understanding social reality. While the model of Christian theology consists of: the model of Christian theological understanding in pre-academic period, academic period, and contextual academic period.

Keywords: pluralism, religion, tradition

\section{A. Pendahuluan}

Salah satu persoalan teologis yang sangat mendasar dalam kehidupan keagamaan di era modern sekarang ini adalah masalah hubungan antar agama atau pluralisme agama (religion pluralism). Walaupun masalah ini bukan sesuatu yang baru sama sekali, namun sebagaimana lazimnya sebuah wacana, tentu saja kemunculannya tidak berdiri sendiri, tetapi banyak faktor yang melatarbelakanginya. Salah satunya ialah apa yang disebut oleh Gilles Kepel sebagai krisis modernita (Kepel, 1993: 191).

Pluralisme agama berusaha mengusung agenda terciptanya jalinan hubungan antar umat beragama secara harmonis, khususnya dalam masyarakat majemuk yang selalu diwarnai oleh adanya pasang surut dan tidak selamanya harmonis, baik pada skala lokal, regional, nasional, maupun internasional. Meskipun doktrin (ajaran) agama masing-masing mengajarkan keharmonisan, kedamaian, kerukunan, dan saling membuka diri, namun dalam realitas historisempiris doktrin agama, keputusan majelis ulama, keputusan konsili, dan kesepakatan dewan gereja-gereja sedunia yang agung tersebut, belum dapat terlaksana sebagaimana yang diharapkan (Abdullah, 2000: 5-6). Amin Abdullah (2000:6) mensinyalir bahwa banyak faktor yang menjadi kendala betapa kerukunan antar umat beragama begitu sulit diwujudkan. Diantara faktor-faktor tersebut, 
semisal faktor kepentingan politik, ekonomi, sosial, pertahanan keamanan yang ikut mewarnai pergumulan, juga adanya dinamika dan pasang surut hubungan antar umat beragama. Ditambah lagi oleh bercampuraduknya aspek doktrin-teologis dalam pergumulan kultural-historis menambah semakin rumitnya persoalan keagamaan pada wilayah historis-empiris kemanusiaan.

Pluralisme dalam kehidupan pemeluk beda agama, sesungguhnya telah dimulai sejak lama. Islam dalam usianya yang relatif amat masih muda harus menghadapi kenyataan objektif adanya pluralitas agama, sosial, budaya, etnis, dan sebagainya. Lahirnya Piagam Madinah (Watt, 1977: 221-225), bisa dijadikan bukti konkret bahwa Islam begitu concern terhadap persoalan pluralisme, demikian juga sebaliknya agama-agama lain. Orang yang pertama kali mempercayai dan memproklamirkan wahyu yang diturunkan kepada nabi Muhammad adalah seorang Kristen (Lewis, 1988: 21-25), Waraqah ibn Naufal, dan ketika umat Islam mengalami intimidasi dari orang-orang Quraisy Mekkah, migrasi kaum Muslimin pertama adalah ke Abessinia dimana rajanya Najashi (Negus) beragama Kristen, dan rakyatnya menyambut kedatangan umat Islam sebagai sesama orang yang beriman kepada Tuhan (Davies, 2000: 1-2).

Demikian juga, nabi memperlakukan dengan begitu hormat terhadap tamu kenegaraan meski berbeda agama. Ketika nabi mendapat kunjungan dari delegasi Nasrani KatolikNajran, rombongan yang datang tidak kurang dari 60 orang, dipimpin oleh Abd al-Masih al-Ahyan dan seorang Uskup bernama Abu Harits ibn Alqamah, mereka tinggal beberapa hari di Medinah, sebagian ditampung di Masjid Nabawi dan sebagian lagi tinggal di rumah-rumah sahabat nabi (home stay). Tentu saja, selama mereka di Madinah dialog tentang agama tidak terelakkan. Ketika pemimpin delegasi meminta izin meninggalkan masjid karena hendak mengadakan kebaktian dengan rombongan, nabi mencegahnya sambil mempersilahkan melakukan kebaktian di dalam Masjid Nabawi (Ishaq, 1970: 270-271).

Di dalam kehidupan sosial, nabi pun menunjukkan bahwa pluralisme tidak perlu membuat anggota masyarakat merasa canggung dalam bergaul apalagi saling mencurigai antara satu pemeluk dengan pemeluk agama lainnya. Tolong menolong antara mereka dibina 
dengan baik. Bila ada yang ragu ketika disuguhi makanan oleh teman yang berbeda agama, nabi seraya menunjuk ayat al-Qur'an bahwa makanan orang Islam boleh dimakan oleh masyarakat Ahl al-Kitab, dan begitu juga sebaliknya, makanan atau masakan mereka halal dimakan oleh orang Islam (Shihab, 1996: 366-369).

Masih dalam pergaulan sosial, nabi melarang orang Islam membalas ejekan orang lain sekiranya masih bisa ditempuh dengan cara yang lebih menyejukkan suasana, misalnya pernah terjadi sekelompok orang Yahudi datang kepada Rasulullah, seraya mengucapkan "salam" ejekan, as-sam 'alaika (selamat bercelaka engkau hai Muhammad). Mendengar ucapan itu, dan merasa tidak salah dengar, 'Aisyah menjawab emosional, 'alaikum as-sam wa al-la'nah (yang celaka kamu, bahkan semoga ditambah laknat). Mendengar jawaban 'Aisyah demikian, nabi menegurnya dan meminta supaya menahan diri dan ia hanya disuruh menjawab wa'alaikum saja (Baqi, juz III, vol. 3: 53).

Pasca kenabian, Khalifah Umar ibn Khathab pernah melakukan perjanjian dengan penduduk Yerussalem, yang mayoritas beragama Kristen setelah pembebasan wilayah tersebut. Inti perjanjian tersebut adalah menjamin adanya kebebasan beragama dan hak-hak lainnya dengan syarat harus membayar jizyah sebagai kewajiban mereka (Nasir, 1994: 171-174). Ketika masa kekhilafahan Dinasti Abbasiyah kerjasama antara Islam dengan Kristen tetap dijaga dengan baik. Kerjasama dimaksud mengambil bentuk penterjemahan buku-buku filsafat Yunani dalam bahasa Greka ke dalam bahasa Arab. Nama-nama Hunain ibn Ishaq, Ishaq ibn Hunain, Qustha' ibn Luqa, Hubaisy, dan Isa ibn Yahya, mereka ini adalah penterjemah ulung beragama Kristen (Nasution,1973:11). Karena kepiawaiannya, Hunain ibn Ishaq diangkat menjadi Kepala Perpustakaan Bait alHikmah (Fakhry, 1970: 24-25).

Ketika Islam memasuki Eropa melalui Selat Giblartar ke Spanyol, ekspansi ke wilayah ini, sebagaimana diilustrasikan Armand Abel, pada prinsipnya tidaklah pasukan Tariq ibn Ziyad menaklukkan negeri itu melainkan menerima penyerahannya dan kemudian mendudukinya. Mengingat ketika itu di Spanyol sedang mengalami konflik yang tidak berkesudahan, kondisi politik dan ekonomi tidak menentu, dan secara budaya umat Kristen ditekan oleh Yahudi. 
Lalu dibawah pemerintahan penguasa Muslim, demikian Abel melanjutkan:

Para sahabat Thariq dan Musa sudah merasa puas dengan hanya menagih upeti dan membiarkan warga taklukkan mereka itu mempertahankan hukum dan adapt (termasuk agama) mereka, diantaranya dipertahankannya posisi hierarki tradisional... (Abel, 1983: 244-245).

Kebijakan penguasa Muslim di Spanyol ini telah melahirkan kemajemukan dan pluralisme agama yang tulus dan sejati. Sehingga seorang sejarawan Yahudi, Max I Dimont, sebagaimana dikutip Nurcholish Madjid, melukiskan kondisi tersebut sebagai Spain of Three Religions and one Baedroom (Spanyol dengan tiga agama dalam satu kamar tidur), di sana ada umat Islam, Kristen, dan Yahudi hidup secara damai, terbuka, dan bahagia menyertai serta mendukung peradaban yang gemilang. Padahal sebelum Islam datang ke Spanyol, di sana telah terjadi pemaksaan agama dari Yahudi ke Kristen (Madjid, 1995: 146-164).

Demikian halnya pada masa Turki Utsmani berkuasa, walaupun imperium Islam yang satu ini dikenal sangat ketat menerapkan syariat (hukum) Islam, justeru karena penerapan teoritis nilia-nilai Islam secara konsisten dalam lapangan kehidupan itu. Seorang sejarawan ahli tentang Turki, Bernard Lewis, menyatakan "imperium Utsmaniyah bersifat toleran terhadap agama-agama lain, ini sesuai dengan hukum dan tradisi Islam, rakyat yang beragama Kristen dan Yahudi dalam keseluruhannya, telah hidup aman tentram, walaupun mereka tidak bisa berbaur secara bebas (Kenneth, 1986: 374)." Kondisi ini dapat dipahami, mengingat begitu kuat dan ketat pelaksanaan hukum Islam kala itu.

Dialog antar agama juga sering dilakukan oleh umat Islam, misalnya seorang penguasa Mughal India, Sultan Akbar, memiliki minat yang luar biasa pada dialog antar agama (multilateral dialogue) jauh sebelum lahirnya Parlemen Agama-agama Sedunia. Menurut Mazheruddin Siddiqi, Sultan Akbar mengundang tokoh-tokoh agama dari berbagai penjuru negeri untuk berdialog di gedung yang dibangunnya secara khusus, dimana para pendeta Kristen dari Goa yang mewakili Aquavira dan Monserrate, serta para Rahib Hindu dan Budha datang menghadiri dialog itu (Kenneth, 1986: 339-341). 
Dalam pertemuan dialog itu diperbincangkan berbagai permasalahan sosial keagamaan dengan suasana kesetaraan guna mewujudkan pluralisme dalam kehidupan praksis umat.

Mencermati kasus perkasus suasana pluralisme agama sebagaimana diuraikan di atas, menunjukkan sikap pengakuan nyata para pemeluk agama terhadap keberadaan agam-agama lain dan kesanggupannya untuk hidup berdampingan dalam rangka membangun peradaban yang harmonis. Kesediaan umat Islam untuk hidup bersama dan kenyamanan orang-orang non muslim dalam pengakuan Islam, adalah mustahil tanpa ditopang oleh sikap-sikap yang tulus dan sunguh-sungguh dari setiap umat beragama, serta lahir dari pemahaman ajaran agama yang benar.

Pihak Islam sendiri memandang bahwa masalah kolonialisme dan imperialisme yang dilakukan oleh orang-orang Barat (Kristen) terhadap negara-negara yang mayoritas berpenduduk Muslim, merupakan "dosa" yang tidak dapat dimaafkan/diampuni. Selanjutnya, kasus ini yang pada mulanya merupakan kasus yang bermotifkan ekonomi dan politik, kemudian bergeser dan ditariktarik kepada permasalahan ideologi (agama), sehingga kolonialisme dan imperialisme diidentikkan dengan proses kristenisasi atau Penginjilan. Sehingga apapun yang datangnya dari Barat (Kristen), bagi sebagian umat Islam, selalu dicurigai, dibenci, dicaci, dan haram hukumnya.

Sementara itu, ditilik dari sisi teologis-normatif umat Islam dituntut melakukan proses islamisasi, demikian juga umat Kristen memiliki kewajiban yang sama untuk melakukan kristenisasi. Bila dua kepentingan ini bertemu, maka yang terjadi adalah sebuah perselisihan dan tidak jarang menimbulkan konflik. Pada kondisi ini, wajar bila seorang sosiolog, George Simmel, dalam bukunya Conflict: The Web of Group Affiliations memandang bahwa "agama selain menjadi alat pemersatu sosial, juga dapat menjadi sumber konflik." Atau dalam istilah Haryatmoko (Haryatmoko, 2003: 6263), agama memiliki dua wajah, yakni di satu sisi agama merupakan tempat dimana orang menemukan kedamaian, kedalaman hidup, dan harapan yang kukuh. Tetapi di sisi lain, agama sering dikaitkan dengan fenomena kekerasan dan intimidasi. 
Berkenaan dengan terjadinya fluktuasi hubungan antar umat beragama di Indonesia, yang ditandai oleh sederetan peristiwa konflik yang sangat memilukan, kemudian adanya perubahan pandangan baru terhadap masalah pluralisme (the new view of pluralism) pasca kolonialisme, dan semakin merebaknya paradigma posmodernisme (Abdullah, 1993: 108-110) di tengah-tengah masyarakat dunia, maka wacana pluralisme agama kembali mencuat menjadi perbincangan yang banyak dilakukan orang.

Wacana pluralisme tersebut terwujud dalam bentuk aneka ragam dialog yang dilakukan kaum agamawan, kaum intelektual, pemerintah, dan masyarakat umum yang merasa peduli bagi terciptanya pluralisme dalam tatanan kehidupan yang harmonis. Apakah dalam bentuk dialog parlemeter (parliamentary dialogue), dialog kelembagaan (institutional dialogue), dialog teologi (theological dialogue), dialog dalam masyarakat (dialogue in community) atau dialog kehidupan (dialogue of life), dan dialog kerohanian (spiritual dialogua) (Azra, 2000: 20-23).

Berbicara mengenai kota Kudus, Satu hal yang menarik adalah di satu sisi kota ini dikenal sebagai kota santri dan kota wali, tetapi di sisi lain adanya aneka ragam pemeluk agama dalam satu keluarga dalam kondisi yang rukun dan bersahaja merupakan masalah biasa dan telah berjalan cukup lama. Demikian halnya dengan masalah tahlilan bersama, marhabanan bersama, yasinan bersama, kenduren bersama, merupakan kegiatan keagamaan yang biasa diikuti oleh setiap pemeluk agama berbeda.

Mengingat lokus penelitian begitu luas, dan agar arah penelitian menjadi terfokus, maka selanjutnya lokus penelitian ini di batasi di Desa Rahtawu Kecamatan Gebog Kabupaten Kudus. Ada beberapa alasan mengapa daerah ini dijadikan sebagai objek penelitian, diantaranya: (1) Desa Rahtawu Kecamatan Gebog Kabupaten Kudus terletak di lereng Gunung Muria, dimana penduduknya mayoritas warga NU yang taat, tetapi uniknya mereka dapat menerima kehidupan pluralis baik agama, budaya, dan sebagainya; (2) Struktur social-budaya masyarakat Rahtawu masih sangat asli dan lokasinya terisolasi dari daerah lainnya di luar Rahtawu; (3) Masyarakat Rahtawu begitu plural dalam beragama, 
ada yang beragama Islam, Kristen, Budha, dan agama Jawa Kuno (Kejawen); (4) Bagi masyarakat Rahtawu pluralisme agama tidak menjadi satu kendala dalam menjalin interaksi sosial yang harmonis antar pemeluk berbeda agama, tetapi justeru mereka bisa hidup berdampingan satu dengan lainnya dengan penuh persahabatan, saling menghargai, dan kebersamaan, dan (5) Dalam satu keluarga di Rahtawu sudah menjadi biasa adanya pemeluk beda agama, di situ ada Muslim, Kristen, Budha, atau Jawa Kuno bercampur dalam satu kesatuan keluarga yang harmoni dan bersahaja.

Berdasar pada latar belakang di atas, pertanyaan dalam penelitian ini penulis rumuskan ke dalam beberapa point sebagai berikut: (1) Bagaimana aspek historisitas yang melatar belakangi munculnya tradisi kerukuna agama dalam kehidupan pemeluk beda agama di Desa Rahtawu Kecamatan Gebog Kabupaten Kudus? (2) Bagaimana pandangan doktrin teologis pemeluk beda agama terhadap masalah tradisi pluralisme agama dalam kehidupan pemeluk beda agama di Desa Rahtawu Kecamatan Gebog Kabupaten Kudus? (3). Bagaimana aspek sosial-budaya yang mengiringi mulculnya tradisi pluralisme agama dalam kehidupan pemeluk beda agama di Desa Rahtawu Kecamatan Gebog Kabupaten Kudus? (4) Kontribusi apa saja yang dapat diperoleh dari adanya penelitian terhadap fenomena tradisi pluralisme agama dalam kehidupan pemeluk beda agama di Desa Rahtawu Kecamatan Gebog Kabupaten Kudus terhadap pengembangan ilmu pengetahuan?

Berkenaan dengan tulisan yang dibahas, permasalahan dan tujuan penelitian yang ingin dicapai, penyusunan penelitian ini menggunakan jenis peneitian kualitatif dengan pendekatan etnografi, yaitu deskripsi dan interprestasi kelompok atau sistem budaya atau sosial (Creswell, 1998: 58). Menurut Spradley, etnografi merupakan pekerjaan mendiskripsikan kebudayaan (Spradley, 2006: 3). Data lapangan disajikan dalam bentuk tulisan yang merupakan data hasil pengamatan lapangan desa Rahtawu Kecamatan Gebog Kabupaten Kudus. 


\section{B. Pembahasan}

\section{Membangun Tradisi Pluralis dalam Perspektif Pendidikan Islam}

Tradisi pluralisme agama yang terjadi di desa Rahtawu antara Islam dengan Kristen yang demikian kental sudah barang pasti tidak terbentuk secara tiba-tiba, tetapi tradisi itu terbentuk melalui suatu proses yang cukup panjang. Untuk itu, maka pendapat yang bertumpu pada multi perspektif menjadi sangat niscaya, apakah perspektif historis, sosial-budaya, ekonomis, geografis, idioloigis, dan seterusnya.

Bila pandangan tersebut dipandang tepat, maka ada beberapa faktor yang akan mempengaruhi terbentuknya tradisi pluralisme agama antara Islam dengan Kristen di Desa Rahtawu Kecamatan Gebog Kabupaten Kudus, yaitu:

\section{a. Faktor Budaya (Islam-Jawa)}

Masuknya Islam ke daerah Rahtawu berlangsung secara damai, hal ini dapat dilihat dari berbagai situs kuno yang begitu lengkap dan masih utuh, baik berupa patung para dewa, patilasan, dan makam-makam para Begawan yang notabene beragama Budha. Sekiranya Islam dikembangkan di Rahtawu dengan cara kekerasan atau dengan perang, sangat mungkin semua situs-situs kuno itu dihancurkan dan dihilangkan sama sekali sehingga tidak berbekas.

Tetapi yang terjadi tidak demikian, dengan masuknya Islam ke Rahtawu telah terjadi proses akulturasi budaya antara nilainilai Islam dengan budaya Budha yang sudah lebih dulu dan sudah lama berada di Rahtawu. Barang kali ini proses ini mirip dengan proses terbentuknya Islam Jawa dimana hadirnya Islam ke tanah Jawa kemudian terjadi proses sinkritisasi antara tradisi Islam yang baru datang dengan tradisi Hindu-Budha. Proses sinkritisasi ini dikemudian hari melahirkan "agama” baru yang sama sekali berbeda dengan agama Islam dan agama Hindu-Budha, yakni kejawen (kebatinan).

Mengingat proses perkembangan agama Budha dan Islam melalui suatu proses hubungan yang saling menguntungkan (mutualisme) antar kedua belah pihak, maka hal ini telah melahirkan 
satu sikap harmoni dan pluralis dari masyarakat Rahtawu. Proses perkembangan agama-agama yang terjadi di Rahtawu nampaknya mengikuti teori tersebut, tidak terkecuali proses perkembangan agama Kristen, sehingga perilaku harmoni-pluralis ini telah melahirkan tradisi pluralitas agama antar Islam dengan Kristen.

\section{b. Faktor Geografis}

Tradisi pluralitas agama antar Islam dengan Kristen, boleh jadi, juga dilatarbelakangi oleh karena secara geografis daerah Rahtawu sangat rawan dan sangat berbahaya bagi keselamatan setiap penduduknya, karena keseluruhan daerah Rahtawu pada dasarnya adalah tebing batu padas yang sangat curam. Kondisi geografis yang demikian ini jelas setiap saat akan selalu mengancam setiap penduduk yang menetap di Rahtawu. Dari sini akan muncul sebuah kesadaran dari setiap warga akan arti penting hidup bersama, saling menghormati dan menghargai satu dengan lainnya, berperilaku harmonis dan pluralis dalam setiap segi kehidupannya.

Siapa pun dan dimana pun, sekelompok orang yang sedang dalam kondisi terancam, maka sekelompok orang tersebut akan berkomitmen untuk bersatu dalam rangka menghindarkan diri dari keterancaman. Tradisi pluralisme agama yang terjadi antar Islam dengan Kristen di desa Rahtawu, demikian juga dengan agama lainnya, pada dasarnya merupakan modal yang harus dibayar oleh setiap individu masyarakat Rahtawu dalam rangka menghindarkan diri dari kondisi alam yang demikian mengancam keselamatan.

Di samping itu, posisi dan letak daerah Rahtawu yang terisolir dengan daerah lainnya, juga akan melahirkan suatu sikap harmonis dan kebersamaan antar sesama penduduk, saling menjaga, saling membantu, saling sokong, dan saling menghargai satu dengan lainnya. Pendek kata, kalau tidak baik dengan tetangga lantas mau dengan siapa lagi sementara semua mereka terisolir dari masyarakat dan dunia luar sana.

\section{c. Faktor Sosial}

Bagi masyarakat Rahtawu dalam hubungan dengan sesama umat manusia, terutama dalam interaksi sosial, terdapat falsafah hidup yang harus dipegangi dengan seksama, yaitu falsafah Tri Tunggal (tiga tetapi hakikatnya satu). Inti dari falsafah ini pada 
dasarnya adalah menyatunya unsur-unsur agama Jowo, agama Islam, dan agama Kristen, berjalan sama-sama, seiring seirama, dalam rangka mengatur dan mengarahkan perilaku hidup masyarakat.

Dengan falsafah Tri Tunggal tersebut, setiap warga di Rahtawu melakukan interaksi sosial secara mudah, luwes, dan harmonis dengan setiap elemen masyarakat dari berbagai latar belakang yang berbeda, apakah perbedaan tersebut yang berhubungan dengan masalah etnis, budaya, status sosial, bahasa, bahkan agama. Kesemuanya itu bagi masyarakat Rahtawu dipandang sebagai sesuatu yang bersifat aksiden bukan esensi, sebab esensi dari kesemuanya pada dasarnya satu, yaitu nilai yang berdasar pada ketuhanan.

\section{d. Faktor Pemahaman Teologis}

\section{1) Model Pemahaman Teologis Masyarakat Rahtawu}

Ada satu keyakinan yang melekat demikian kuat pada sebagian besar warga desa Rahtawu, bahwa suatu daerah bisa tenang, suatu wilayah bisa tenang, suatu negara bisa tenang, apabila menyatunya kitab kang papat, yaitu menyatunya antara kitab Zabur, kitab Taurat, kitab Injil, dan kitab al-Qur'an. Menurut beberapa tokoh lintas agama, bila keempat-empatnya sudah menyatu, bersatu padu, maka kondisi daerah akan tenang, adem tentrem, harmonis, dan selamat.

Keyakinan tersebut demikian kuat mereka pegangi, terutama pada kalangan orang-orang tua (wong sepuh) yang notabene penganut kejawen atau orang-orang yang dalam Kartu Tanda Penduduk (KTP) nya Islam, tetapi mereka tidak komitmen dengan keislamannya, tidak pernah solat, tidak puasa, tidak mengaji, tidak jum'atan, dan perilakuperilaku lainnya. Kondisi ini juga terjadi pada agama-agama lainya, seperti pada pemeluk agama Budha dan Kristen.

Semakin kuatnya mereka memegang keyakinan tersebut, sehingga muncul satu sikap pada diri mereka bahwa semua agama itu pada dasarnya benar, tidak ada yang salah, siapa pun bisa memeluk agama-agama tersebut kapanpun mau. Mengingat keyakinan dan sikap sebagian besar warga demikian, maka bagi masyarakat desa Rahtawu, khususnya warga dusun Wetan Kali di Rahtawu, sangat mudah sekali seseorang berpindah-pindah agama, tahun ini si A beragama Budha, tahun berikutnya dia beragama Kristen, dan pada tahun berikutnya dia beragama Islam, demikian juga tahun 
berikutnya dia bisa beralih pada agama Budha lagi, yang demikian ini sering dan banyak terjadi.

2) Model Pemahaman Teologi Islam

Bila dihayati secara lebih mendalam, sesungguhnya model pemahaman umat Islam terhadap teks-teks agama (al-Qur'an dan al-Hadis), tidak bisa terlepat dari empat model epistemologi yang selama ini berkembang, yaitu epistemologi bayani, 'irfani, burhani, dan amali. Keempat epistemologi ini memiliki cara pandang sendirisendiri ketika menyikapi nash al-Qur'an dan sunnah. Epistemologi bayani begitu terikat dengan nash al-Qur'an dan sunnah, sehingga ia tidak bisa menghindar sedikitpun dari teks. Epistemologi burhani justru sebaliknya cenderung mengabaikan nash-nash al-Qur'an dan sunnah dan lebih mengutamakan fenomena-empirik sebagai objek kajian. Epistemologi 'irfani berdiri di antara kedua paradigma bayani dan burhani, ia lebih memilih pengalaman sebagai sumber utamanya. Sementara corak epistemologi amali mendudukkan dimensi praktis pelaksanaan ajaran Islam sebagai objek kajian, dengan memposisikan al-Qur'an dan sunnah sebagai grand concepts dan grand theory (Kadir, 2003: 52-55).

Perlu disadari, pesan kemanusiaan dan keadilan yang ditawarkan al-Qur'an dan sunnah sebagai rahmatan li al-alamin yang demikian universal, hanya dapat dipahami dengan baik, jika para penafsir kitab suci kontemporer memahami keempat corak epistemologi pemikiran keislaman tersebut, dan mampu mendialogkan secara kritis-dinamis-proporsional baik secara pribadi maupun kelompok, sehingga ekslusivitas pemikiran dan kelembagaan sosial keagamaan dapat dihindari sedini mungkin, dan kerjasama antara berbagai kelompok sosial-keagamaan menjadi niscaya, tanpa harus mendahulukan prejudice-prejudice kultural, sosial, maupun keagamaan. Hanya dengan demikian, akhirnya semua perhatian bisa difokuskan untuk menyelesaikan berbagai persoalan praktis kehidupan umat, dengan tetap bernaung di bawah pesan moral universal al-Qur'an dan sunnah sebagai rahmatan li al-alamin. Beberapa model pemahaman teologis dalam Islam diantaranya mencakup: 


\section{a. Model Pemahaman Teologis Bayani}

Filsafat ilmu yang dikembangkan di dunia Barat, seperti rasionalisme, empirisme, dan pragmatisme, dalam pandangan Amin Abdullah tidak begitu cocok untuk dijadikan kerangka teori dan analisis terhadap pasang-surut dan perkembangan Islamic studies (2003: 12). Perdebatan, pergumulan, dan perhatian epistemologi keilmuan di Barat tersebut lebih terletak pada wilayah natural sciences dan bukannya pada wilayah humanities dan social sciences. Sedangkan Islamic studies dan 'ulumuddin, khususnya syariah, aqidah, tasawuf, 'ulum al-qur'an, dan 'ulum al-hadis, lebih terletak pada wilayah classical humanities. Untuk itu, diperlukan perangkat kerangka analisis epistemologis yang khas untuk pemikiran Islam, yakni apa yang disebut oleh Muhammad Abid al-Jabiry dengan epistemologi bayani, 'irfani, burhani, dan epistemologi amali (Kadir, 2003).

Menurut al-Jabiry, corak epistemologi bayani didukung oleh pola pikir fikih dan kalam. Dalam tradisi keilmuan agama Islam di UIN, IAIN, dan STAIN, mungkin juga pengajaran agama di perguruan tinggi umum negeri dan swasta, dan lebih-lebih di pesantren-pesantren, corak pemikiran keislaman model bayani sangat mendominasi dan bersifat hegemonik sehingga sulit berdialog dengan epistemologi 'irfani dan burhani. Corak pemikiran 'irfani (tasawuf, intuitif, al-'atify) kurang begitu disukai oleh tradisi berpikir keilmuan bayani (fikih dan kalam) yang murni, lantaran bercampuraduknya bahkan dikaburkannya tradisi berpikir keilmuan 'irfani dengan kelompok-kelompok atau organisasi- organisasi tarekat dengan satahat-satahatnya, serta memang kurang dipahaminya struktur fundamental epistemologi dan pola pikir 'irfani berikut nilai manfaat yang terkandung di dalamnya.

Sebenarnya ketiga kluster sistem epistemologi Islam, 'ulumuddin ini (dalam tulisan ini menjadi empat, ditambah epistemologi amali), sebagaimana digambarkan al-Jabiry, adalah masih berada dalam satu rumpun, tetapi dalam praktiknya hampirhampir tidak pernah mau akur. Bahkan tidak jarang saling kafirmengkafirkan, murtad-memurtadkan, dan sekuler-mengsekulerkan antara masing-masing penganut ketiga tradisi epistemoilogi ini. Oleh karena itu, pola pikir tekstual bayani lebih dominan secara 
politis dan membentuk mainstream pemikiran keislaman yang hegemonik. Sebagai akibatnya, pola pemikiran keagamaan Islam model bayani menjadi kaku dan rigid. Otoritas teks dan otoritas salaf yang dibakukan dalam kaidah-kaidah metodologi ushul fikih klasik lebih diunggulkan daripada sumber otoritas keilmuan yang lain, seperti alam (kauniyyah), akal (aqliyyah), dan intuisi (wijdaniyyah) (Abdullah, 2003: 13-14).

Dominasi pola pikir tekstual ijtihadiyyah menjadikan sistem epistemologi keagamaan Islam kurang begitu peduli terhadap isuisu keagamaan yang bersifat kontekstual bahtsiyyah. Menurut Amin Abdullah (2003: 14), pengembangan pola pikir bayani hanya dapat dilakukan jika ia mampu memahami, berdialog, dan mengambil manfaat sisi-sisi fundamental yang dimiliki oleh pola pikir 'irfani maupun burhani, dan begitu pula sebaliknya. Menurut Amin Abdullah dalam Jarot Wahyudi, Jika saja masing-masing sistem kefilsafatan ilmu keagamaan dalam Islamic studies ini berdiri sendirisendiri, tidak bersentuhan antara satu dan lainnya sebagaimana yang tercermin dengan kokohnya dinding-dinding pembatas fakultas di lingkungan UIN, IAIN, dan STAIN, serta Perguruan Tinggi Agama Islam Swasta, belum lagi tembok pembatas antara keilmuan umum dan keilmuan agama yang selama ini terus dilembagakan, maka agak sulit dibayangkan akan terjadi pengembangan ilmu-ilmu keislaman yang siap pakai dalam menghadapi problem-problem kontemporer (2003: 3-18).

Kelemahan yang paling mencolok dari tradisi nalar bayani atau tradisi berpikir tekstual-keagamaan adalah ketika ia harus berhadapan dengan teks-teks keagamaan yang dimiliki oleh komunitas, kultur, bangsa, atau masyarakat yang beragamna lain. Dalam berhadapan dengan komunitas lain agama, corak argumen berpikir keagamaan model tekstual bayani biasanya mengambil sikap mental yang bersifat dogmatik, defensif, apologis, dan polemis, dengan semboyan kuranglebih semakna dengan "right or wrong is my country". Itulah jenis pengetahuan keagamaan yang biasa disebut-sebut sebagai al-ilm altauqifi, yang dibedakan dari al-'ilm al-huduri dan al-'ilm al-husuli dalam tradisi pemikiran Islam klasik. Hal demikian dapat saja terjadi karena fungsi dan peran akal pikiran manusia tidak lain dan tidak bukan hanyalah digunakan untuk mengukuhkan dan membenarkan otoritas 
teks. Sama sekali di luar kalkulasi pendukung corak epistemologi ini, apakah pelaksanaan dan implementasi ajaran teks dalam kehidupan masyarakat luas masih orisinal dan seotentik lafal teks itu sendiri atau tidak, karena diskusi seperti ini akan diintrodusir dan diambil alih oleh pemikiran model paradigma burhani (Abdullah, 2003: 14-15)

Sebagaimana dimaklumi bahwa kebenaran teks yang sipahami dan diakui oleh aliran, kelompok, atau organisasi tertentu belum tentu dapat dipahami dan diakui secara sama dan sebangun oleh aliran, kelompok, atau organisasi lain yang menganut agama yang sama. Belum lagi harus ditambahkan di sini bahwa kebenaran teks yang dipahami dan diakui oleh penganut agama tertentu pasti berbeda dari kebenaran teks yang dipahami, diakui, dan diyakini oleh penganut agama yang lain. Dari sinilah sumber munculnya apa yang disebut dalam tradisi ilmu kalam sebagai al-uqul al-mutanafisah, pola berpikir jadaliyyah atau dialektik. Jika dirujuk kebelakang, pola logika yang bisa digunakan fuqaha dan mutakallimun adalah pola logika dan cara berpikir yang biasa digunakan oleh Stoik (Stoics, al-Rawaqiyyun) dan bukannya pola logika yang digunakan oleh Aristoteles.

Dengan demikian, peran akal pikiran dalam memahami dan menafsirkan hal-hal yang terkait dengan soal-soal keberagamaan atau religiusitas manusia memang sangatlah terbatas. Sejak dari dulu pola pikir epistemologi bayani lebih mendahulukan dan mengutamakan qiyas (qiyas al-'illah untuk fikih dan qiyas al-dalalah untuk kalam), dan bukannya mantiq lewat silogisme dan premis-premis logika. Epistemologi tekstual-lughawiyyah (al-asl wa al-far'; al-lafz wa al-makna) lebih diutamakan daripada epistemologi kontekstualbahtsiyyah maupun spiritualitas-irfaniyyah-batiniyyah. Di samping itu, nalar epistemologi bayani selalu mencurigai akal pikiran, karena dianggap akan menjauhi kebenaran tekstual (al-Jabiry, 1990: 29-30).

\section{b. Model Pemahaman Teologis 'Irfani}

Menyatunya "teks" dan "akal" rupanya memunculkan kekakuan dan ketegangan tertentu, bahkan tidak jarang, sebagaimana disinyalir Chandra (1992), konflik dan kekerasan yang bersumber dari pola pikir ini. Untuk menghindari kekakuan dan rigiditas dalam berpikir keagamaan yang menggunakan teks sebagai sumber utamanya, epistemologi pemikiran keagamaan Islam, sesungguhnya 
telah mempunyai dan menyediakan mekanisme control perimbangan pemikiran dari dalam (internal control) lewat model berpikir epistemologi 'irfani. Model epistemologi 'irfani lebih bersumber pada intuisi dan bukannya teks. Ditilik dari sejarahnya, model epistemologi ini telah ada baik di Persia maupun Yunani jauh sebelum datangnya teks-teks keagamaan baik oleh Yahudi, Kristen, maupun Islam.

Namun status dan keabsahan epistemologi irfani selalu dipertanyakan baik oleh tradisi berpikir bayani atau burhani. Epistemologi bayani mempertanyakan keabsahannya karena dianggap terlalu liberal dan tidak mengikuti pedoman-pedoman yang diberikan teks. Sedang epistemologi burhani mempertanyakan keabsahannya karena dianggap tidak mengikuti aturan-aturan dan analisis yang berdasarkan logika. Apabila dalam tradisi sejarah pemikiran Islam, apa yang disebut intuisi, ilham, qalb, dlamir, dan psikognosis telah terlanjur dikembangkan dan diinstitusionalisasikan menjadi apa yang disebut-sebut sebagai "tarekat" dengan wirid-wirid dan satahat-satahat yang mengiringinya (Rahman, 1979: 132-133). Agak sulit mengembalikan citra positif epistemologi irfani dalam pangkuan gugus epistemologi Islam yang lebih komprehensifutuh-integrated karena kecelakaan sejarah dalam hal kedekatannya dengan perkumpulan tarekat. Padahal tarekat itu sendiri tidak lain dan tidak bukan adalah institusional atau organizational expression dari tradisi Gnosis (tasawwuf) dalam budaya Islam. Fazlur Rahman sampai-sampai pernah menyebutnya sebagai "religion within religion" (Rahman, 1979: 150).

Untuk mengembalikan intuisi pada pengertian epistemologis bukan institusi atau organisasi sosial-keagamaan diperlukan keberanian untuk melakukan passing over dengan meminjam khazanah tradisi pemikiran eksistensionalis di Barat. Falsafah Barat pun pernah mempertanyakan dominasi dan keangkuhan rasionalitas dalam sejarah pemikiran mereka. Di sini diperlukan keberanian untuk melakukan rekonstruksi dan reformulasi pemikiran Islam dalam wilayah tasawwuf-irfani era kontemporer, seiring munculnya tuntutan-tuntutan untuk lebih melihat dan mencermati kembali dimensi spiritualitas dalam Islam (Abdullah, 2003:17).

Jika sumber pokok ilmu pengetahuan dalam tradisi bayani 
adalah teks (wahyu), maka sumber ilmu pengetahuan dalam tradisi 'irfani adalah pengalaman (experience). Pengalaman hidup seharihari yang otentik, sesungguhnya, merupakan pelajarn yang tidak ternilai harganya. Ketika manusia menghadapi alam semesta yang cukup mengagumkan dalam lubuk hatinya yang terdalam telah dapat mengetahui adanya Dzat yang Maha Suci dan Maha Segalanya. Untuk mengetahui Dzat yang Maha Pengasih dan Penyayang, orang tidak perlu menunggu turunnya teks (Waling, 1985: 245-252). Pengalaman konkrit pahitnya konflik, kekerasan dan disintegrasi sosial dan akibat yang ditimbulkannya dapat dirasakan oleh siapapun, tanpa harus dipersyaratkan mengenal jenis-jenis teks-teks keagamaan yang biasa dibacanya.

Pengalaman-pengalaman batin yang amat mendalam, otentik, fitri, hanafiyyah samhah, dan hampir-hampir tak terkatakan oleh logika dan tak terungkapkan oleh bahasa inilah yang disebut-sebut sebagai al-ilm al-huduri (direct experience) oleh tradisi isyraqi di Timur atau preverbal, prerecletive consciousness atau prelogical knowledge oleh tradisi eksistensialis di Barat (Solomon, 1972: 255-257). Semua pengalaman otentik tersebut dapat dirasakan secara langsung oleh seluruh umat manusia apapun warna kulit, ras, budaya, dan agama yang dipeluknya, tanpa harus mengatakannya terlebih dahulu lewat pengungkapan bahasa maupun logika. Validitas kebenaran epistemolog irfani hanya dapat dirasakan dan dihayati secara langsung (al-ru'yah al-mubasyirah; direct experience), intuisi, al-dzauq atau psikognosis. Sekat-sekat formalitas lahiriyah yang diciptakan oleh tradisi model epistemologi bayani maupun burhani baik dalam bentuk bahasa, agama, ras, etnik, kulit, golongan, kultur, tradisi, yang ikut andil merenggangkan dan mengambil jarak hubungan interpersonal antara umat manusia, ingin diketepikan oleh tradisi berpikir orisinal 'irfani. Spiritualitas-esoterik yang bersifat lintas agama, bahasa, dan kultur bukannya eksternalitas-eksoterik yang lebih menekankan identitas lahiriyah agama, bahasa, ras, kulit, kultur yang ingin dikedepankan oleh corak nalar epistemologi 'irfani.

Untuk itulah, prinsip memahami kebenaran orang, kelompok, dan penganut gama lain (verstehen, understanding others) dengan cara menumbuhsuburkan sikap empati, simpsti, social skill, serta berpegang teguh pada prinsip-prinsip universal reciprocity (bila 
merasa sakit dicubit, maka janganlah mencubit orang lain) akan mengahantarkan tradisi epistemology irfani pada pola pikir yang lebih bersifat unity in difference, tolerant, dan pluralist (Askari, 1991: 69-90).

Dengan demikian, hubungan antara subjek dan objek bukannya bersifat subjektif (seperti yang biasa dalam tradisi bayani) dan bukan pula bersifat objektif (seperti yang biasa terjadi dalam tradisi burhani), tetapi lebih pada intersubjektif. Kebenaran apapun, khususnya dalam hal-hal yang terkait dengan kehidupan sosialkeagamaan adalah bersifat intersubjektif. Apa yang dirasakan oleh penganut suatu kultur, ras, agama, kulit, bangsa tertentu dengan sedikit tingkat perbedaan juga dirasakan oleh manusia dalam kultur, ras, agama, kulit, dan bangsa yang lain.

Disnilah perlunya rekonstruksi dan pemahaman ulang arti istilah ittihad, fana, dan juga hulul yang biasa diambil dari khasanah pemikiran tasawuf klasik yang sering dikritik oleh para fuqaha dan mutakallimun baik klasik maupun kontemporer. Konsep wihdah al-wujud bukannya berarti manunggaling kawulo gusti, tetapi lebih berarti unity in multiplicity atau unity in difference. Baik wihdah al-wujud, hulul, maupun ittihad bukannya berarti menyatunya unsur ketuhanan dan kemanusiaan, tetapi lebih mengandung arti menyatunya basic human need (kebutuhan sandang, pangan, papan, afilitas keagamaan atau religiusitas, makna kehidupan yang paling dalam atau spiritualitas, kebutuhan untuk aktualisasi diri, dan sebagainya), tanpa terlalu memandang perbedaan ras, kulit, etnis, dan agama. Itulah pemahaman baru tentang apa yang disebutsebut sebagai ittihad al-a'rif wal ma'ruf. Istilah bila wasithah (tanpa perantara) dan bila hijab (tanpa sekat) bahkan juga kasyf al-mahjub hanya dapat dipahami dengan mencarinya batas-batas formal antar agama, etnis, kelamin, ras, dan sebagainya (Abdullah, 2003: 19).

Dalam pengertian dan makna seperti itulah agama-agama dapat dimaknai dan diinterpretasikan ulang secara lebih mendalam, eksoterik, bathiniyyah, ruhaniyyah. Untuk itu kajian-kajian baru dan serius tentang kerangka berpikir epistemologi 'irfani akan sangat kesulitan menghadapi realitas pluralitas keberagamaan umat manusia, baik internal maupun eksternal. Hanya pola pikir epistemologi irfani inilah yang dapat mendekatkan hubungan sosial antar umat 
beragama, meskipun secara sosiologis mereka tetap saja sah untuk tersekat-sekat dalam entitas dan identitas sosial-kultural mereka sendiri-sendiri lewat tradisi formal-tekstual keagamaannya. Dalam tradisi epistemologi "irfani, istilah "arif" lebih diutamakan daripada istilah "alim", karena alim lebih merujuk pada nalar bayani, sedang arif lebih merujuk para tradisi irfani. Secara sosialogis, budaya, dan masyarakat Indonesia juga lebih menghormati karakter arif dan bukannya alim untuk hal-hal yang terkait dengan kompleksitas pergaulan sosial, budaya, dan keagamaan.

\section{c. Model Pemahaman Teologis Burhani}

Berikutnya epistemologi ketiga adalah epistemologi burhani. Ibn Rusyd, sebagai tokoh filosof Muslim klasik, telah menyebutnyebut jenis epistemologi ini (Abdullah, 2003:20). Namun, hegemoni epistemologi bayani menjadikan corak epistemologi burhani dan juga 'irfani tersingkir dari panggung sejarah pemikiran keislaman. Oleh karena keduanya yakni epistemologi burhani dan 'irfani cukup vital perannya dalam pemikiran keislaman, maka keduanya perlu direkonstruksi ulang dengan pemaknaan-pemaknaan yang baru (alqira'ah al-muntijah), untuk mendampingi paradigma bayani.

Jika sumber ilmu (the origin of science) dari epistemologi bayani adalah teks, sedang 'irfani adalah direct experience, maka epistemologi burhani bersumber pada realitas atau al-waqi', baik realitas alam, sosial, humanitas maupun keagamaan. Ilmu-ilmu yang muncul dari tradisi burhani disebut sebagai al-ilm al-husuli, yakni ilmu yang dikonsep, disusun, dan disistematisasikan lewat premispremis logika atau al-mantiqi, dan bukannya lewat otoritas teks atau salaf dan bukan pula lewat otoritas intuisi (Abdullah, 2003: 20).

Premis-premis logika keilmuan tersebut disusun lewat kerjasama antara proses abstraksi (al-maujudat bari'ah min al-madah) dan pengamatan inderawi yang sahih atau dengan menggunakan alat-alat yang dapat membantu dan menambah kekuatan indera, seperti alat-alat laboratorium, proses penelitian lapangan (grounded research) dan penelitian literer yang mendalam. Peran akal pikiran sangat menentukan di sini, karena fungsinya selalu diarahkan untuk mencari sebab-akibat (idrak al-sabab wa al-musabab) (al-Jabiry, 1990: 20). 
Puspo Nugroho

Untuk mencari sebab dan musabab yang terjadi pada peristiwa-peristiwa alam, sosial, kemanusiaan, dan keagamaan, akal pikiran tidak memerlukan teks-teks keagamaan. Untuk memahami realitas kehidupan sosial-keagamaan dan sosial-keislaman, menjadi lebih memadai apabila digunakan pendekatan-pendekatan seperti sosiologi, antropologi, kebudayaan, dan sejarah. Fungsi dan peran akal bukannya untuk mengukuhkan kebenaran teks seperti yang ada pada nalar bayani, tetapi lebih ditekankan untuk melakukan analisis dan menguji terus menerus (heuristik) kesimpulan-kesimpulan sementara dan teori yang dirumuskan lewat premis-premis logika keilmuan. Ibn Rusyd sangat menekankan proses kerja akal pikiran seperti ini sebagaimana yang dilakukan dan dikonseptualisasikan oleh Aristotle. Fungsi akal pikiran yang bersifat heuristik dengan sendirinya akan membentuk budaya kerja penelitian, baik yang bersifat eksplanatif, eksploratif, maupun verifikatif.

Tolok ukur validitas keilmuan pun sangat berbeda dari nalar bayani dan nalar 'irfani. Jika nalar bayani tergantung pada kedekatan dan keserupaan teks atau nash dan realitas, dan pada nalar 'irfani lebih pada kematangan social skill (empati, simpati, verstehen), maka dalam nalar burhani yang ditekankan adalah korespondensi (almutabaqah baina al-aql wa nizam al-tabiah atau kesesuaian antara rumus-rumus yang diciptakan oleh akal manusia dengan hukumhukum alam). Selain korespondensi juga ditekankan aspek koherensi (keruntutan dan keteraturan berpikir logis) dan upaya yang terus menerus dilakukan untuk memperbaiki dan menyempurnakan temuan-temuan, rumus-rumus, dan teori-teori yang telah dibangun dan disusun oleh jerih payah akal manusia (Abdullah, 2003: 21-22).

3) Model Pemahaman Teologi Kristen

Secara garis besar model pemahaman teologi Kristen dapat dibagi menjadi tiga bagian, yaitu (a) Model pemahaman teologi Kristen periode pra akademis, (b) Model pemahaman teologi Kristen periode akademis, dan (c) model pemahaman teologi Kristen periode akademis-kontekstual. Secara lebih detail penjabarannya sebagai berikut:

a. Model Pemahaman Teologi Periode Pra Akademik

Pembicaraan masalah teologi pada dasarnya adalah wacana 
yang merujuk pada keberadaan Allah. Dengan demikian dapat dikatakan bahwa sang pengkhotbah berteologi. Untuk kepentingan pengajaran (katekese) dan pembelaan (apologia), para teolog merumuskan ajaran-ajaran. Sering kali usaha mereka merupakan jawaban yang tepat terhadap pergumulan pada situasi dan kondisi yang sedang dihadapi. Namun pengaruh kecanggihan dan keberhasilan rumus-rumus ini menyebabkan generasi penerus merasa tidak perlu lagi menjawab tantangan zaman mereka sendiri. Sesuatu yang berhasil pada masa lalu mesti berhasil juga pada masa kini, dan demikian juga pada masa yang akan datang. Generasi penerus lantas berhenti pada pengertian "penerus" saja, padahal tidak ada rumus teologi yang bisa diterapkan tanpa usaha kreatif untuk mengadakan interpreteasi dan reinterpretasi. Mereka sudah tidak berteologi lagi, dan akhirnya usaha inipun terhenti.

Pasca perang dunia II, sekitar tahun 50-an, muncul di sanasini lembaga-lembaga pendidikan teologi, lembaga-lembaga tersebut didirikan oleh gereja, pada waktu itu sedang mengahadapi tantangan yang kuat dari sekularisasi, ateisme, dan teknologi, yang dianggap sebagai konsekuensi langsung dari sekulerisasi. Tekanannya adalah pencetakan pendeta-pendeta siap pakai, yang dapat membimbing warga Gereja menghadapi bahaya yang mengancam. Di Indonesia bahaya tersebut masih harus ditambahkan dengan bahaya yang datang dari agama lain, yang dikhawatirkan akan mengancam pola pikir warga Gereja dengan kategori-kategori yang sepintas lalu kelihatannya mirip.

Maka dalam kurikulum tekanan utama adalah pada penguasaan ajaran-ajaran berdasarkan suatu pandangan teologis tertentu. Suasananya sangat skolastik, dengan mata kuliah Dogmatik sebagai "prima dona." Selain itu juga Homiletik yang membuat seorang pendeta bisa mengkomunikasikan ajaran dengan canggih. Pandangan-pandangan lain dari teologi yang dominan juga diberikan, namun menurut metode explaining away, dalam artian menerangkan sesuatu dalam rangka menyapu bersih tanpa toleransi sedikit pun terhadap realitas asing. Dalam metode semacam ini yang muncul adalah metode antitesis. 
Puspo Nugroho

b. Model Pemahaman Teologi Periode Akademik

Dalam periode ini biasanya teologi terbagi lagi menjadi teologi jemaat dan teologi akademis. Teologi jemaat adalah reftelksi yang berasal dari perilaku dikalangan para jemaat. Sifatnya sederhana, non ilmiah tetapi tidak dangkal. Teologi akademis beredar dikalangan lembaga-lembaga pendidikan teologi dan berusaha mensistematisasi teologi jemaat menjadi sesuatu yang dapat dipelajari dan dipertanggungjawabkan secara ilmiah dan memperhadapkan teologi jemaat pada pandangan-pandangan serta struktur pemikiran yang sedang berlaku di masyarakat yang lebih luas.

Kedua teologi ini seyogyanya saling membutuhkan dan saling melengkapi, seperti dalam pembicaraan konsep Trinitas. Sepanjang sejarah Gereja telah banyak diberikan alternatif-alternatif untuk menerangkan Trinitas secara lebih memuaskan. Teologi akademis berusaha merefleksikan alternatif-alternatif ini dan menghubungkan dengan konteks tempat seorang Kristen berada.

Jika pada masa pra-akademis yang menjadi primadona adalah Dogmatik, maka pada zaman akademis yang menjadi primadona adalah Biblika. Pada zaman pra-akademis orang memang menjunjung tinggi Alkitab sebagai firman Allah. Namun dalam kenyataan yang dijunjung tinggi sebetulnya perangkat rumus-rumus dari suatu ajaran Dogmatis tertentu, yang didukung oleh tafsiran yang sudah tertentu dari ayat-ayat Kitab Suci. Kalaupun ada tafsiran yang dilakukan maka tafsiran sangat diwarnai oleh ajaran dogmatis tertentu itu.

Teologi akademis berusaha melakukan persentuhan dengan dunia ilmu pengetahuan, pergaulan dengan ilmu menyebabkan teologi akademis memanfaatkan banyak penemuan-penemuan dari ilmu-ilmu tersebut. Pergaulan teologi akademis terjadi dengan filsafat, sosiologi, antropologi, psikologi, sejarah, dan seterusnya. Sehingga pada periode teologi akademis ini yang dikedepankan adalah bukan laku beribadah ansich tetapi bobotnya berdasar pada ilmu.

c. Model Pemahaman Teologi Periode Akademik-Kontekstual

Keterpesonaan terhadap teologi akademis yang lebih dapat menghadapi dan menyelesaikan pelbagai persoalan umat manusia yang diakibatkan oleh sekulerisasi dan teknologi berjalan sampai sekitar tahun 70 -an. Pada tahun-tahun berikutnya muncul berbagai 
persoalan umat manusia menyangkut hubungannya dengan berbagai realitas yang demikian majemuk dan plural. Untuk itu, teologi gereja harus berusaha menemukan model teologi baru yang lebih dari teologi akademik, dari kesadaran ini maka munculah teologi akademik kontekstual.

Teologi akademik kontekstual berpandangan bahwa setiap pandangan jemaat harus bertumpu pada sesuatu yang ada pada Alkitab, ilmu pengetahuan, dan konteks budaya setempat. Ketiga entitas tersebut merupakan satu kesatuan yang sinergis dalam menghadapi berbagai persoalan umat manusia (jemaat) dalam menghadapi era yang demikian global.

Selain itu, perlu juga disadari bahwa Indonesia merupakan negara yang pluralistik di bidang agama. Di Indonesia, orang Kristen bergaul dengan orang-orang beriman lain, seperti dengan Islam, Hindu, Budha, Konfusianis, bahkan agama Jawa Kuno (Kebatinan). Teologi akademis kontekstual dengan demikian juga berarti menerima kenyataan berupa kemajemukan agama-agama ini sebagai sesuatu yang perlu dihargai (Singgih, 1997: 125-140).

Harapan yang hendak dicapai dari teologi akademik kontekstual adalah suatu pemahaman yang dapat menerima pemahaman lain sebagai suatu entitas sama seperti entitas yang dimilikinya, dan pada akhirnya terciptanya sebuah tatanan dunia baru yang lebih damai, harmonis, pluralis, dan sejahtera, dalam sinaran cahaya firman Tuhan yang lebih sejati.

\section{Simpulan}

Dari Kajian Diatas Dapat Kita Simpulkan Bahwa sebuah konsep atau teori baru tentang model pluralisme agama. Dalam rangka membangun hubungan yang harmonis antara pemeluk beda agama masyarakat menstranfosmasi nilai-nilai pluralisme agama yang selama ini mengendap pada level kaum elite agamawan, seperti kyai, ustadz, romo, dan pendeta, penguasa, dan seterusnya kepada masyarakat akar rumput. Hssil dari proses tersebut menujukkan bahwa Banyak faktor yang mempengaruhi terbentuknya tradisi pluralisme agama antara Islam dengan Kristen di Desa Rahtawu Kecamatan Gebog Kabupaten Kudus, yaitu: (a) faktor budaya Islam 
Puspo Nugroho

Jawa, (b) faktor geografis, (c) faktor sosial kemasyarakat, (d) faktor model pemahaman teologis yang inklusif.

Adapun melihat proses di atas penulis melihat beberapa model yang berkembang dalam tradisi masyarakat yang plural tersebut. Diantaranya Model pemahaman teologi Islam terdiri dari: (1) model pemahaman teologi bayani, (2) model pemahaman teologi burhani, dan (3) model pemahaman teologi 'irfani. Dalam prakteknya, ketiga model pemahaman teologi ini (bayani, burhani, dan 'irfani) terinterkoneksi dalam memahami realitas sosial. Sementara model pemahaman teologi Kristen terdiri dari: (1) model pemahaman teologi Kristen periode pra akademis, (2) model pemahaman teologi Kristen periode akademis, dan (3) model pemahaman teologi Kristen periode akademis-kontekstual. 


\section{DAFTAR PUSTAKA}

Abdullah, M. Amin, dkk., 2000. Ontologi Studi Islam: Teori dan Metodologi, Yogyakarta: IAIN Sunan Kalijaga.

Abdullah, M. Amin. 1993. Dialog Peradaban Menghadapi Era Posmodernisme: Sebuah Tinjauan Filosofis-Religius. Al-Jami'ah: Jurnal Ilmu Pengetahuan Agama. Yogyakarta: IAIN SUKA Yogyakarta, no. 53.

Abdullah, M. Amin. 2003. Epistemologi Ilmu-Ilmu Keislaman. Yogyakarta: Makalah Simposium Nasional.

Abdullah, M. Amin. 2004. Analytical Perspektive in the Study of Religious Diversity: Searching for a New Model of Philosophy on the Study of Religious, Yogyakarta: International Conference on Religious Harmony: Depag-UIN Jogia-IAIN W.9-IAHR.

Abel, Armand, 1983. "Spayol: Perpecahan dalam Negeri," dalam Gustave Von Grunebaum (ed.), Islam, Kesatuan dalam Keragaman, Jakarta: Yayasan Penghidmatan.

Al-Jabiry, Muhammad Abid. 1990. Bunyah al-Aql al-Arabi: Dirasah Tahliliyyah Naqdiyah li Nudzumi al-Ma'rifah fi al-Tsaqafah alArabiyah, Beirut: al-Markaz al-Tsaqafy al-Arabi.

Al-Jabiry, Muhammad Abid. 1990. Takwin al-Aql al-Arabi, Beirut: alMarkaz al-Tsaqafy al-Arabi

Askari, Hasan. dkk,. 1991. Towards a Spiritual Humanism: A MuslimHumanist Dialogue. Ledds: Seven Mirrors Publishing House Limeted.

Azra, Azyumardi. 1999-2000. "Kerukunan dan Dialog Islam-Kristen di Indonesia," dalam Mursyid Ali (ed.), Dinamika Kerukunan Hidup Beragama Menurut Perspektif Agama-Agama, Jakarta: BPPA-PPKHUB.

Baqi, Fuad Abdul, Al-Lu'lu wa al-Marjan. Beirut: Al-Maktabah al'Ilmiyyah, juz III, vol. 3, t.t.

Chandra, Robby I. 1992. Konflik dalam Hidup Sehari-hari, Yogyakarta: 
Puspo Nugroho

Kanisius.

Creswell, John W. 1998. Research Design: Qualitative and Quantitative Approaches. London: SAGE Publication.

Davies, Merryl Wyn. 2000. "Introduction," in Munawar Ahmad Anees, Syed Z. Abedin, and Ziauddin Sardar, Christian-Muslim Relation: Yesterday, Today, Tomorrow, terj. Ali Noer Zaman, Yogyakarta: Qalam.

Fakhry, Majid. 1970. A History of Islamic Philosophy, New York: Columbia University Press.

Gellner, Ernest. 1992. Posmodernism: Reason and Religion, New York: Routledge.

Haryatmoko. 2003. Etika Politik dan Kekuasaan, Jakarta: Kompas, cet. 1 .

Ishaq, Ibn. 1970. Sirah Rasul Allah, translate A. Guillaume, The Life of Muhammed, Lahore Karachi-Decca: Oxford University Press.

Kadir, Muslim A. 2003. Ilmu Islam Terapan: Menggagas Paradigma Amali dalam Agama Islam, Yogyakarta: Pustaka Pelajar, cet. 1.

Kepel, Gilles. 1993. The Revenge of God: Resurgence of Islam, Christianity, and Judaism in the Modern World. Pennsylvania: The Pennsylvania State University Press.

Leaman, Oliver. 1988. Averroes and His Philosophy, Oxford: Clarendon Press.

Lewis, Bernard. 1986. “Turki: Westernisasi," dalam Kenneth W. Morgan (ed.), Islam: Kesatuan dalam Keragaman, terj. Tim Pustaka Jaya, Jakarta: Pustaka Jaya.

Lewis, Bernard. 1988. The Arabs in History, terj. Said Jamhuri, Bangsa Arab dalam Lintasan Sejarah, Jakarta: Pedoman Ilmu Jaya.

Madjid, Nurcholish. 1995. Islam Agama Kemanusiaan: Membangun Tradisi dan Visi Baru Islam Indonesia, Jakarta: Yayasan Paramadina. 
Nasir, Syed Muhamadun. 1994. Islam Its Concepts and History, terj. Adang Affandi, Islam, Konsep, dan Sejarahnya, Bandung: Remaja Rosdakarya,

Nasution, Harun. 1973. Filsafat dan Mistisisme dalam Islam, (Jakarta: Bulan Bintang.

Permata, Ahmad Norma dkk (ed.). 2000. Metodologi Studi Agama. Yogyakarta: Pustaka Pelajar.

Rahman, Fazlur. 1979. Islam, Chicago: The University of Chicago Press.

Rusyd, Ibn. 1981. Tahafut al-Falasifah, Beirut: Daar al-Ma'arif.

Shaban, M.A. 1993. Islamic History, terj. Mahnun Husaini, Sejarah Islam, Jakarta: PT Raja Grafindo Persada,

Shihab, M. Quraish. 1996. Wawasan al-Qur'an, Bandung: Mizan.

Singgih, Emanuel Gerrit. 1997. Reformasi dan Transformasi Pelayanan Gereja Menyongsong Abad Ke-21, Yogyakarta: Kanisius.

Solomon, Robert C. 1972. From Rationalism to Existensialism: The Existentialist and Their Nineteeth Century Backgrounds, New York: Harper \& Row Publisher.

Spradley, James. P. 2006. Metode Etnografi, Terjmh: Elizament, M.Z., dari The Etnografi Interview), edisi II. Yogyakarta: Tiara Wacana.

Wahyudi, Jarot, (ed.). 2003. Menyatukan Kembali Ilmu-Ilmu Agama dan Umum, Yogyakarta: IAIN SUKA Press.

Waling, Frank, (ed.). 1985. Contemporary Approaches to the Study of Religion. Berlin: Mounton Publisher.

Watt, W. Montgomery. 1977. Muhammad at Madina, OxfordEngland: The Clarendo Press.

Woodward, Mark R. 1999. Islam Jawa: Kesalehan Normatif versus Kebatinan, Yogyakarta: LKiS. 
halaman ini bukan sengaja dikosongkan 